\title{
The Investigation of the Jurisprudential Review of the Principle of Acquittance and Its Effects in International Law
}

\author{
Hosein Rahimi \\ Ph.D. Student, Department of Jurisprudence and the foundations of Islamic law, Qom Branch, Islamic Azad \\ University, Qom, Iran. \\ Hamid Kaviani Fard \\ Associate Professor, Department of Jurisprudence and the foundations of Islamic law, Qom Branch, Islamic \\ Azad University, Qom, Iran. (Corresponding Author) \\ Esmat Al-Sadat Tabatabayi Lotfi \\ Associate Professor, Department of Jurisprudence and the foundations of Islamic law, Qom Branch, Islamic \\ Azad University, Qom, Iran. \\ Nasrin Karimi \\ Associate Professor, Department of Jurisprudence and the foundations of Islamic law, Qom Branch, Islamic \\ Azad University, Qom, Iran
}

\begin{abstract}
One of the arguments is the "Principle of Atonement". If, after referring to the evidence, a doubt arises in the religious duty, the principle of acquittance says that the duty is forbidden. The subject of the principle of acquittance (doubt in the assignment is not obligatory), that is, in cases where we doubt it, we believe that we are not obliged to do so in practice and that the assignment is void. The present paper deals with the methodology of librarianship and documents on the basis of the principle of acquittance, the stage of crime detection, the stage of prosecution, the stage of the trial and the issuance of the sentence and discussed them. The principle of acquittance is one of the most important and effective rules in international law and human rights instruments, since the heavy burden of claiming the cause of the claim and the claim is put forward by the defendant, in other words, the presentation of the cause lies with the claimant and the oath. It is inconceivable that global and regional human rights declarations have repeatedly stated that no one can be arbitrarily detained, imprisoned or exiled, and that the principle is based on acquittance.
\end{abstract}

Keywords: principle of acquittance, regulations, human rights

DOI: $10.7176 /$ RHSS/9-3-08

\section{Introduction}

The presumption of acquittance is one of the principles that both principles of jurisprudence and in the field of doubt in the homework are considered by scholars of principles and criminal law as one of the most important principles that guarantees criminal justice and the most solid basis of social security accused in the field of acquittance. The time to prove the charge is raised by the attention of lawyers and lawmakers. According to this principle, all individuals in the innocent society are assumed unless their charge is prosecuted beyond the reasonable doubt in the competent judicial authority. In spite of the general rule of the principle of acquittance in criminal matters, this principle is limited in exceptional cases and in the interests of the material.

The essential role of this principle is to determine the practical task for the duty if it is in doubt. If the accused did not find reason, the scholars of the science of the principles ruled that this principle should be inappropriate and not obligatory. After "wisdom and despair of the religious order", although some of the Islamic scholars who have become famous for Hadith Companions, considered the duty of such a person to be suspicious of the sanctity, namely the sanctions ruling. The evolution of the original principle is that if there is doubt about something that is worthy of allegiance, and that there is no reason to believe it, then this doubt in the homework will come from three areas: A) the absence of a letter; B) ageneral knowledge; C) The controversy which is said to be a hypothetical sentence, that is, where the subject is specific, but the ruling of the matter is not known, whether it is a claim or a sanction. 
But if the general ruling of the matter is clear, then doubts about the particular subject found, in other words, in the external issue or in the minor ruling that is the source of the mistake in foreign affairs, is called a controversial issue. Solve this doubt by examining foreign affairs, and it has nothing to do with the law, and the obligation to eliminate doubt must go to the custom and rationale.

Therefore, if it is doubtful whether the duty in the principle of duty is in the existence of a religious order of necessity or sanctity, is well-known in the case of the principals in this case, the principle of abandonment, the abandonment of reason and transgression.

Intellectual exclusion means that, regardless of the judgment of the suspect in relation to the suspicious event of Al-Hakam, reason is based on the rule of "the tribulation of the evil eagle", which is a rational rule. And religious exclusion means that it is not necessary to take caution in respect of doubt in the verdict, rule, or principle, which is the religious exclusion (the elimination of us La Ya'alon), that is, the legislator of Islam against the dubious duty and suspicious event of the guardianship. The verb, or the abandonment of that suspicious, is reserved. Therefore, the principle of acquittance is invaluable in international law and human rights instruments.

\section{Concepts}

\section{1-1 Principle}

The principle in the word means the root, foundation, source, and race (ibn Manzour, 1416, p. 1, p. 15). Principle versus subsidary body, for example, in relation to analogy, it is said that: being drunk is the main principle for the unbelievers (Wine is the origin of the fruit), that is, to use the wine ruling to rule on the wrongdoing, and in the words of the owner of the wisdom: the principle of the verdict is fixed (on the part of the shah) and the other is a subordinate matter (whose ruling is not expressed by the author and not fixed) (Jebee Ameli, 1418, p. 211).

Principle means pretentiousness and appearance, (prefix), for example, to say that truth is the principle permitted (ie, al-faqalam al-hagiqa), ie, when it is undecided, between verbal deliverance on its true or natural meaning, bearing on the truth of the principle. It means preference and truth is a clear meaning of the word of the word. It should be a symbol to say the word from the truth to the permissible meaning, henceforth its term is called "Sarafeh", that is, the handler and the "guardian" are also referred to as the suppression of the true meaning. Principle means the reason, the discoverer of something, and the guide to this thing, for example, to prove the verdict, say: "The principle of the Holy Prophet (s) of the Holy Qur'an; that is, the proof of this is the judgment." (Vol. 1388, p. 85)

In the words of Sheikh Ansari (ra), the main thing that the late Allameh Heli (ra) and his followers have said have meaningful meanings, which are:

(1) The principle is to refer to (firstly, to the human mind) which the late Mohaqi al-Thani has referred to as one of the main meanings of the universe, and has conquered the way of its study. That is, the message is necessary, and the origin of this emergence is overcome; in other words, it is permissible for every one hundred instances in the community; $95 \%$ of it is necessary and $5 \%$ is allowed.

2. The term "principle" means "the rule of the public", which is referred to as Isla'al, which is, as isal-al-'Amum or 'Islat al-'atlāq, a literal principle. This rule originates from a general public, such as (O'Fawa al-Dawaqud), (Ahlullah al-Abdullah), (the land of the Malawi, Muslims) and (Al-Mu'minun al-Shurehtam).

So, when it comes to doubt about the necessity and the permissibility of the claim, according to the'Asalah alZazum ', arising from the public, we need it.

3. The original meaning of isșāhab (Mahan's retention); that is, after the transaction and termination of one of the parties, we doubt whether the seller will withdraw from the customer's property or not? According to the "principle", the decree prescribes the survival of the customer in the property of the client.

4. The fourth meaning of the "principle" is that its meaning is the same as the lexical meaning of the principle; that is, the root and the primordial essence; in that the expression of the root and the foundation itself is necessary, unless it is imperative Like cucumbers from outside it (Ansari, 1429, p. 19-17).

The evolution of "principle" in the legal language includes one of these four meanings:

1. Appearance: As they say, the person who deals is the principle that he is for himself, unless this is the case (Article 196), that is, the appearance is that he trades in his name and account. On behalf of others, or in the 
definition of the claimant, "one is the one whose statement is contrary to the principle", that is, his claim is opposed to the principle or appearance or "the principle is in the words of the truth" ... and so on.

The word appearance in Article 256 of the Civil Code states: "Anyone who gives financially to another will appear to be in disrepute ..." and the original word can be used instead.

2. Rule: The rule is the general rule from which partial sentences are obtained, and the subject of it is not a work or a special event: the rule of lawlessness, which is also called "the principle of misconduct". In Article 356 of the Civil Procedure Code, which states that "the principle is indissoluble ..." or in the "principle of necessity of transactions" (Article 219 of the Criminal Code), this is the intended meaning. But we will see that the "legal framework" today has a more meaningful meaning.

3. Relation: As Article 357 of the Civil Procedure Act states: "If a person's right or religion is proved to be the responsibility of one, it is the principle of survival unless proved to be wrong." And the purpose of the principle is ascetic.

4. Reason: When it is said that the principle of this theory of law or custom is the basis, and the reason for it is taken from the law and the custom (Katouzian, 1380, 2, pp. 626-625).

Given the abovementioned legal meanings, it seems that the term "principle" in the original principle of adultery is fully in line with the legal meaning of the rule and can be regarded as the synonym of the rule in the sense of a high law. The original term, in principle, is also due to its literal meaning ( $\mathrm{Pi}$, Foundation).

The concept of the rule in this regard applies to the concept of principle, which is an example of the legal concept of the principle in the sense of the rule, conforms to the meaning of the legislator's meaning. An example is that according to Article 356 of the Civil Procedure Code (Article 197 of the Civil Procedure Code of 1379), the principle is innocent; in this article, the principle is the rule. That is, the basis and foundation of the prosecution is a claim, and the claimant must prove it against it, and it can even be said that in this sense also corresponds to the legal meaning of the rule. It is a general rule based on which partial judgments are obtained. These partial rulings on the principle of vindication include: the obligation of the claimant to provide reasons and to prove the claim, the unenforceability of the accused to prove his acquittance, the non-conviction of the accused, his right to remain silent, his right to be guilty if he doubts. Suppose that there are several other minor sentences which can be deduced from the general rule of the principle of acquittance. It is believed that "the principle of acquittance, in the broad sense that we find in our law, is based on many other principles: as the principle of prudence of works, the principle of the validity of contracts, the principle of the rule of will and the freedom of contracts, And the principle of the complementarity of the laws is one of the basic principles of abandonment "(Katouzian, 1380, p. 3, p. 426).

It also seems to fit in the legal sense with the first concept (appearance). Because the legislator has made the appearance of those who are accused of committing a crime against their offense, unless it appears to be the opposite. In other words, as in the transaction that a person performs, the appearance is that he carries out a transaction for himself unless it is proven that it is also in criminal law that the offender is not charged with committing the crime unless That's the opposite.

But it can not be understood by the third and fourth meanings. Because they are the two main elements in the foresight of the former and the dictatorship. Since we often have no certainty about the former acquittance, but if we are certain of the acquittance of a person, then the principle can be understood as meaning the aspire with the meaning of the principle of acquittance, because, with doubt, we must investigate around doubt, and if the former certainty, with doubt, And finally, by providing a reason for a definite justification, it should not be converted into a criminal offense, we must proceed with the principle of ascetic (innocent accused). But given that, firstly, the judgments are issued on the basis of prevailing rulings, and not rare, secondly, the perception of it as the principle may create the notion that the principle of atonement is also construed as one of the principles in the sense of jurisprudence, which then may be The discussion of the primacy of the principles or the priority of the sentence is based on the principle, it cannot be interpreted as meaning the principle of asceticism.

In view of the above, it is apparent that the principle is not consistent with the fourth meaning.

The Sheikh Ansai (ra) states: The principle only applies to the authentication of cucumbers in a marriage contract, because cucumber is a right outside the essence of the marriage and its proof is to be reasoned. But if there is a need for and permission for another contract, except the bid. Principle does not necessarily mean the necessary lexical meaning of the marriage, since the doubt source at this time is in doubt in the Shari'a order (does it make it obligatory for the marriage contract or the right to do so?) That the word " Slow and overtaking is necessary, it is a good talk, but can it be possible to prove peace, Ja'ahl, and other marriages with it? Therefore, the reason is a 
particular claim, because our claim is any contract that is doubtful about its necessity and permission, and our reason is specific (Ansari, 1429, p. 8). So the best meaning for the "principle" is the second meaning; the rule.

\subsection{Acquittance}

\section{The Notion of Lexical Meaning of acquittance}

The word Acquittal in the word means to get rid of defect and slander, to escape from debt, to dislike something and to purify it (ibn al-'Mahr, 1416 pp. 34 and 31). It means being away from what is said to be approaching it. (Ragheb Esfahani, 1419, p. 121). In the sense of purity, cleansing from defect, liberation and getting rid of (Zubaidi, 1388, p. 1, p. 506), liberation, deliverance, freedom from doubt, dislike something. (Teriqi, 1412, p. 1, p. 493), according to the abovementioned meaning, it can be seen that in the literal sense of acquittance, the words of salvation and distraction have been most used, and these words in the legal sense of transgression are also affected in the sense of the law as we deal with it.

The fundamental role of this principle is to determine the practical duty for the obligation, if doubtful, in the actual judgment; That is, if the obligation in the sanctity or the necessity of the object or the current, for doubting the reason or conclusiveness of it or the conflict, doubts the reason and after an inquiry, has not reasoned, the scholars of the science of the principles according to this principle, decide that they are innocent and not obligated to do so. Meshkini Ardebili, 1374, p. 46).

Although some other Islamic scholars who have become known as the "Journalists" consider the duty of such a person to be precautionary in doubting their sanctity. (ibid, p. 47)

In the term of the use of acquittance in various jurisprudence is as follows:

1. acquittance to the duty, which means that you are not obliged to enter into the probable duty (the principle of atonement).

2. acquittance to religion is meant to be liberated from religion because of its temptation or the fall of religion from obedience

3. The acquittance of the womb; it means that it is clear whether it is pregnant or not.

4. acquittance means defamation from the seller against the defects of the traded goods. If the seller claims that during the transaction, he has defaced the defects and the buyer denies it, if he does not have the word, the customer's word can be accepted with an oath (Karaki, 1411, p. 354).

5. acquittance means defective guarantee of self-harm to the potential injuries from the person's area to the other.

The doctor's resignation from the guarantor when he or she treats the patient leads to a collapse of the guaranty (Najafi, Bita, p. 22, pp. 47-46).

6- Swear to be acquitted of God, or the Messenger of Allah (PBUH), or the infallible Imams (AS); meaning to withdraw from the divine power or from the province and the details of his arguments. It is not permissible to swear allegiance to God, the Prophet (s), or one of the Imams (AS), and does not concede it and, according to the famous promise, does not guarantee the atonement (Khoiy, 1389, pp. 265-260).

7. acquittance from the enemies of God and his parents means the abhorrence of the heart from them and the practice of its compliance with behavior and speech, such as avoiding them and curseing them, which in its term is interpreted as "Tabari".

8- Acquittance from inheritance means the loss of its share of inheritance from Jerra; it means denial of commitment and liability to crime.

Father's transgression from the son of Jirra (walaa) and his share in the inheritance (waists) does not result in the father's deprivation from the inheritance of the child (Naraqi, 1419, p. 19, p. 312).

But some of the ancients considered it to be the father's deprivation of the inheritance of the child.

\section{2. the presumption of acquittance and its types}

Inferiority in Shia jurisprudence, especially in later periods, is based on two stages; first, the search is due to the religious order; that is, the book, tradition, consensus, and reason. Second, refer to practical principles. 
The practical principle is an expression in the principles of jurisprudence in the sense of the rules that, in cases of doubt in the determination of the religious order, clarify the obligatory practical task after it has not been obtained for reasons and acts. In other words, the principles of action are principles that determine the practical task of someone who is skeptical, so the subject of the principles of action is doubt. The principle of practice, which is also said to be the cause of par excellence.

The principle of acquittance is one of the main principles of the practice which determines the practical task in cases where it doubts the real task after seeking and obtaining the reason, and decides on its admissibility the suspicious task; and, in practice, It does not oblige the duty to perform that task; for example, when it is inconceivable to suspect the obligation of Friday prayers when it is obliged, after searching and not reaching for reasons, that the guilty principle has come to an end, then it is not obligatory for him to perform Friday prayers and not to do so Do not be tormented. Therefore, whenever there is a doubt about the duty of the principal, and there is no reason to clarify the duty for the obligation, that task is not required.

The principle of acquittance from the point of view of the scholars of the principles of jurisprudence is twofold:

\subsection{Rationality}

The rational exclusion is that, by virtue of reason, it is not obliged, in the exercise of any duty, to perform any task in relation to a suspect task, after having been investigated and not reaching for a reason, and this allegation is based on the rational rule of the tribe of the Eagle, because it is ruled by reason It is ugly and insulting anyone who has not told him something about the task, so he will not be obliged to answer the eagle.

\subsection{Religious vindication}

The religious offense, that is to say, in every suspicious item that does not obey the principle of the true decree, the sacrament is obliged to put an obligation by placing a verdict. The scholars of jurisprudence have stridden to narratives in order to prove their religious vindication. (Sadr, 1426; pp. 29-46). With a focus on jurisprudential and legal issues, the principle of acquittance has consequences in international human rights law and regulations, which is discussed below:

3. The effects of the principle of acquittance in international law and human rights instruments

\subsection{Crime Detection}

In order to detect a crime, individuals must be monitored, searched, and controlled. It is from the works of the principle of acquittance that individuals are treated like other citizens in order to prove the crime in a competent court. Therefore, the seizure and auditing of the person is contrary to the principle of acquittance and must be subject to certain formalities.

\section{The "Prohibition of Hostage" has been identified and emphasized in the Universal Declaration of Human Rights. Article 9 of the Universal Declaration of Human Rights}

\subsection{Crime Detection}

In order to detect a crime, individuals must be monitored, searched, and controlled. It is from the works of the principle of acquittance that individuals are treated like other citizens in order to prove the crime in a competent court. Therefore, the seizure and auditing of the person is contrary to the principle of acquittance and must be subject to certain formalities.

The "Prohibition of Hostage" has been identified and emphasized in the Universal Declaration of Human Rights. Article 9 of the Universal Declaration of Human Rights states: "No one can be arbitrarily detained, imprisoned or exiled." Article 3 of the declaration also states: "Everyone has the right to life, liberty and security of person." Also, the prohibition of inspections in Article 12 of the Universal Declaration of Human Rights has been recognized as follows: "No one shall be subjected to arbitrary interference in his private life, family, home or correspondence, and his honor and reputation shall not be subject to Attack. Everyone has the right to be protected against such attacks and interventions. "According to Article 13, everyone has the right to travel freely within each country and choose their place of residence. In these articles, the principles of the prohibition of exploration, prohibition of the seizure and the prohibition of the control of the identity of individuals are recognized and these principles must be observed at the stage of crime detection.

The International Covenant on Civil and Political Rights has also paid attention to some of the effects of the principle of atrocities at the stage of crime detection. According to Article 9 of the Covenant, "Everyone has the 
right to liberty and security of person. No one can be arrested or arrested arbitrarily (without permission). No one can be deprived of liberty except in the directions and according to the procedure prescribed by law and in accordance with the law. "Article 17 of the Covenant has also recognized the prohibition of exploration and prosecution.

The Islamic Declaration of Human Rights of Cairo, adopted in 1411 AH, states in Article 18: "Every human being has the right to live in comfort with respect to his life, religion, family, and his family and his property, and have autonomy in his private affairs. It is not permissible to spy or monitor her, or to distort her dignity; Housing is at the same time deserving and should not be entered without the permission of its inhabitants or illegally, "the declaration in article 20 prohibits the arrest or restriction of the freedom of individuals except Shari'a has been approved.

The European Convention for the Protection of Human Rights and Fundamental Freedoms, adopted in 1950, also states that, under the guilty principle of being prosecuted, the crime of detection, inspection, seizure, arrest and control of the identity of individuals must be observed. According to Article 5 of the Convention, everyone has the right to liberty and security, and no one shall be deprived of his liberty unless otherwise provided by law. The Convention also provides for the principle of non-disclosure and inspection of persons in Article 8: "Everyone has the right to respect for his private life and correspondence." Paragraph 2 of this article provides for inspection and investigation only in accordance with the law and when National security, public health, economic well-being of the country, the maintenance of order and the prevention of crime, the protection of health or morality, or the protection of the rights and freedoms of others is warranted.

The American Convention on Human Rights, adopted in 1969, also contains principles in the stage of the discovery of a crime. According to paragraph 1 of article 5 of the convention, "Everyone has the right to respect his physical, mental and moral integrity." Also, Article 7 stipulates: "No one shall be deprived of physical liberty except for reasons and according to pre-determined conditions. The constitution of the country relates or is based on the law established by the constitution.

The African Charter on Human Rights, adopted in 1981, also contains principles similar to other instruments for crime, including Article 4.

Based on the above materials, identity checks, inspections and detainees are in violation of the right to liberty and security of the person, and should comply with the principle of acquittance when necessary to inspect and control their identity.

But the most important international document is the Statute of the International Criminal Court (Rome Statute), 1998. According to Article 54 of the Statute of the Prosecutor, in order to discover, actually, during the investigation, consider all relevant and substantiated evidence, in a way that can determine whether the essence of the criminal liability of the provisions of this Statute has been achieved. If the answer is yes, they will investigate the circumstances and arguments against the defendants in an impartial manner. And finally, respect for the rights of individuals arising from the provisions of this Statute. " The International Criminal Court does not confine itself to a national tribunal that may violate the fundamental rights of individuals, and, in the event of the inability of national systems to enforce rights of individuals, it exercises its competence, (p. 1384, p. 141). According to article 55 of the statute, in the course of the investigation, persons shall not be subjected to coercion, reluctance, threat, torture or any cruel, inhuman or degrading treatment or punishment, and may receive free assistance from a mighty translator. Individuals should not be arbitrarily arrested unless otherwise directed in accordance with the statutes. A person suspected of having committed crimes within the jurisdiction of the Court has the right to be informed before his interrogation of his / her right (ibid., P. 142).

A look at the international and regional human rights instruments related to the principle of atrocities suggests that these steps should be routine. The purpose of the inspection procedure is that the competent authorities cannot, in any way they wish, and whenever they wish to inspect, this requirement derives from the principle of the legality of the procedure and the principle of exclusion, according to which the salaries of persons in Under the pretext of selflessness, government workers are protected and protected (Ansari, 1380, p. 294).

\subsection{At the stage of pursuit}

At the prosecution stage, the prosecution should be discarded as a criminal offender to prove his charge in a competent court and many rights and privileges are also recognized for the accused. The publication of photos and wanted persons is prohibited. 
Article 8 of the Universal Declaration of Human Rights states that everyone has the right to an effective remedy to competent national courts against acts that violate the fundamental rights of the individual and those rights are conferred by the Constitution or another law.

Article 8 of the International Covenant on Civil and Political Rights also states that no one shall be arbitrarily arrested or detained. No one shall be deprived of liberty except in accordance with the procedure prescribed by law. Anyone arrested should be notified when arrested.

As soon as possible, he or she should not be held liable to trial or any other person permitted by law to exercise judicial authority. The arrest of persons awaiting trial should not be a general rule, but temporary release may be subject to obtaining guarantees to ensure the presence of the defendant at the hearing and other stages of the proceedings and execution of the sentence. The person deprived of his liberty has the right to sue the court and the court must comment on the legality of the detention without delay, otherwise he will order him to be released, and finally, everyone illegally arrested or detained, the right to claim damages Will have.

According to the Statute of the International Criminal Court, the person suspected of committing one of the offenses under the jurisdiction of the Tribunal has the right, before interrogating his or her particular rights, the right to know that he is suspected of having committed a crime, the right to remain silent without the silence at trial a reason for his guilt or acquittance, the right to legal assistance and the right to interrogate in the presence of a lawyer, unless he has waived his right to do so. In accordance with Article 69 of the Statute, the violation of these rules makes it possible for the Court of Justice to withdraw the confession that it derives from its findings. Guarantee of fundamental rights, immediate and immediate right to information about the causes of his arrest and the charges against him, and the right to trial without delay is a suspect under the terms of the Rome Statute.

There is no specific rule about the way information is provided to the suspect, but there is no need for a written notice. Also, the relevant information may be provided to him at a later stage, provided that he is provided promptly and promptly. Judgment of compliance with or non-compliance with this command must be made in each case separately. In addition, the suspect has the right to go to an impartial judiciary to reconsider whether or not to detain himself; this is the same thing as Kamnlow's legal system is rightly sued based on the summons of a wellknown prisoner. According to one of the accepted and established principles of international human rights law, pre-trial detention is legally permissible unless it exceeds a reasonable period of time. (Gita Shayzari, 1383, p. 534)

The alleged acquittance of the accused constitutes the basis of the criminal justice system until the crime has been proved. Hence, the unplanned delay in investigating or detaining an unjustified suspect is a shield that marks the heart of the hearing system.

According to Article 59 of the Statute of the International Criminal Court, a person who is arrested at the request of the Prosecutor of the Court shall be immediately brought before the competent judicial authority of the country where he was detained and, in accordance with his country's law, determine the position of the said person, including whether the rights of the person Has this been observed or not? Such a person will also have the right to apply to the competent authority in the country where the detention is based and request temporarily to be released when the assignment is due or not delivered to the court.

According to Article 5 of the European Convention on Human Rights, anyone arrested should immediately be informed of the reasons for his arrest and accusation against him in a language that he understands and be immediately brought before a judge or judge authorized by law to exercise judicial power. And has the right to be released within a reasonable time, before the trial, and to file a lawsuit in which to decide quickly on whether or not to arrest him in court, and if he is arrested illegally, his release order is issued. Anyone who has been the victim of arrest or detention has the right to seek redress contrary to the provisions of this Article (Article 5).

The American Convention on Human Rights has the same rules in Article 7, and the African Charter on Human Rights has also referred to the same necessities in article 6.

\subsection{The trial stage}

The most important works of the principle of atrocities at the trial stage are the following: immediate notification of the alleged charge, guaranteeing the defendant's right to defense, guaranteeing the defendant's silence, the plaintiff's or prosecution's duty to provide reasons, observance of the principle of equality before the law and the court, the interpretation of doubt The benefit of the accused, the right to access to the charge file and to know all the reasons he has been educated against him, the right to enjoy all social and political rights before issuing a decree and the entry into force, the need to prove acquittance by the defendant, the right to submit the latest defense, 
the right to object to sentences and sentences issued before they are finalized, the need for separation of temporary detention centers from prisons $\mathrm{Q}$ in reference to the sentence above.

Article 10 of the Universal Declaration of Human Rights makes a fair and public hearing about the right to sue individuals through the independent, impartial tribunal and declares that only such a court has the right to decide on the criminal charge of individuals. Also, based on Article 11 of the Declaration, Public Litigation and the Prosecution of Persons shall be carried out with due observance of all the guarantees required for defense. Also, no one shall be convicted of any act or omission which was not criminalized at the time of the commission of the act in accordance with national international law.

The International Covenant on Civil and Political Rights also clearly states the principles of a fair trial in Article 14. Everyone is equal before the courts and tribunals of the judiciary, and everyone has the right to be fairly and publicly prosecuted in an independent and impartial tribunal established by law. The Covenant makes an exception to the open trial and states that it is possible in all or part of the proceedings, in the interests of good morals, public order or national security in a democratic society or in the interests of the private life of the parties to the lawsuit or in terms of harm from the publicity of the meetings to the judiciary, the decision to proceed with the trial is taken. The Covenant therefore insists that the sentence issued in criminal matters will be public.

According to article 14, paragraph 3, of the Covenant, anyone accused of committing a crime should, with full equality of rights, have sufficient time and facilities to defend himself and contact his chosen lawyer. He will be judged without any delay. To stand trial and defend himself or herself personally by his / her lawyer and if he / she does not have a lawyer, he / she will be informed of his / her right to have a lawyer and, in cases where the court has jurisdiction, he / she will be assigned a lawyer by the court. If he or she cannot afford to pay your wages, you can ask questions or ask questions from the witnesses against him, and the intuitions that he testifies can be summoned and questioned by the same conditions of intuition. If a language spoken in court does not understand or cannot speak, a freelance translator will help him. Do not be forced to testify against yourself or confess to being guilty.

The Cairo Islamic Declaration of Human Rights also referred to article 19 (e) of the fair trial and stated that all guarantees should be provided to defend the defendant in court.

The European Convention for the Protection of Human Rights and Fundamental Freedoms also referred to the same guarantees in Article 6, and also Article 8 of the American Convention on Human Rights, which confirmed the fair trial as one of the important works of the principle of acquittance. The African Charter on Human Rights also incorporates certain principles of fair trial, including the right to defense, the right to trial within a reasonable time in an independent tribunal, the right of appeal to competent national authorities in Article 7.

The International Criminal Tribunal's Statute, in Article 67, regarding the principles governing the fair trial of the accused for any accusation, has the right to be tried in public, in a fair and equitable manner, and in compliance with the following minimum guarantees in equality:

A. In the language the accused fully understands and talks with, he will immediately and accurately be informed of the nature, causes and content of the charge.

B: Give him sufficient time and facilities to prepare his defense and to communicate freely and confidentially with the defense lawyer himself chooses.

C: To be tried without undue delay.

D: In accordance with paragraph 2 of Article 63, in order to exercise the defense personally, or through a legal counsel of his choice, be present at the trial and be informed that if he is not a legal adviser, he shall be entitled to the assistance of a legal adviser who, if necessary, And to provide justice, even if it does not have the financial means to pay for the related costs

E: From the intuitions brought against him, ask questions promptly or by another and present their witnesses to the meeting and ask them to answer them in accordance with the conditions in which they have been intimated.

F: If the court proceedings or evidence presented in a trial is in a language other than the language spoken by the accused, he can freely benefit from the assistance of an interpreter, as well as translations that are required in a fair trial.

G: The accused is not compelled to testify or confess guilt and can silence without being silent as confession or denial. 
H: Can provide written and oral pronunciations without oath.

There is no interdependence imposed on the accused in proving the evidence or refusing it.

\subsection{The stage of issuing the sentence}

Uncertainty, the right to challenge and seek to challenge a court order prohibiting a double trial of a person's rights at the stage of issuing a sentence.

According to article 14, paragraph 5, of the Covenant on Civil and Political Rights, "Everyone charged with a criminal offense has the right to file a criminal offense and his authority by a higher court in accordance with the law". This clause has in fact taken into consideration the right of inquiry and objection to the verdict handed down by the court of first instance. Clause 6 of this article declares that if a final sentence of a person's conviction is later violated or if a newly discovered event or cause indicates a mistake and is therefore pardoned, a person who has suffered a sentence as a result of the conviction, Deserves to be compensated for damages under the law unless it is proven that it has not been promptly disclosed to the accused in person, in whole or in court. "Article 14, paragraph 14, of the Covenant also prohibits prosecution and prosecution of the defendant. And declares that no one shall be subjected to the offense committed by virtue of a definitive ruling made in accordance with the Code of Criminal Procedure Each country has been convicted or acquitted, prosecuted and punished again.

The American Convention on Human Rights recognizes the right of inquiry to a higher court in Article 8 and has confirmed the right to a retrial. Article 9 of the present Convention has turned into non-compliance with the criminal law as one of the effects of the principle of atrocities at the time of the issuance of the sentence, and Article 10 also states that anyone who, if he has been punished with a definite warrant for breeding, is entitled He will be compensated in accordance with the law.

Article 20 of the International Criminal Court Statute also stipulates the refusal to double the trial again for a crime, and according to article 47, paragraph 3 , of the statute, judges should try to obtain the unanimous vote of the court and if unanimity is not achieved, , Voting will be with the majority. Also, according to Article 81 of the Statute, the defendant has the right to appeal against decisions on conviction or punishment by the Court.

\section{Conclusion}

The most important reason is the validity of this principle of reason, in fact, the rational basis (the tribe of the Eagle is blatantly expressed), and the purpose of this rule is that it is ugly and unwise that it is punishable and punished by anyone for doing what is forbidden and forbidden. And wisdom rules. If there is doubt and lack of sufficient evidence, it is a judgment of acquittance.

The principle of acquittance, as one of the principles governing criminal law and criminal proceedings, which has a profound connection with the preservation of individual rights and freedoms in society, has enjoyed a high status in international human rights instruments, as well as in the constitution and ordinary laws of the Republic Islamic Republic of Iran also has a legislative base. According to the International Covenant, no one can be arbitrarily arrested or arrested. No one can be stripped of freedom except by law.

Therefore, in accordance with the principle of acquittance, you must be held at the stage of crime detection, inspection, seizure, arrest and control of the identity of the individuals, and the principle is based on acquittance unless proved to be appropriate in the competent court.

\section{References}

1. Ansari, Morteza, 1995, Makbas, Mostafavi Publication, Qom.

2. Ansari, Morteza, 1418, Faryad al-Asal, General Assembly of the Islamic Republic, Qom.

3. Ansari, Morteza, 1429, Rasaleh, Naser-i-Alahiya Eltrahat, Beirut.

4. Bastani, Abdullah, 1999, Mojtaba Bostan, Isfahan Publishing House, Tehran.

5. Gity Shayzari, Krygensak; 2004; International Criminal Law, Translator: Behnam Yousefian and Mohammad Esmaeili, Tehran, Department of Publications.

6. Horrameli, Mohammad ibn Hassan, Wassail al-Shi'a, Volume 18, Tehran: Al-Mektah al-Islamiyah, 1995

7. Hamedani, Reza, 1418, Mesbah-e-Afzieh, Maktaheh Sadr.

8. Heidari, Ali Neghi, 2009, Principles of Agriculture Inference, Islamic Law Publisher, Second Edition.

9. Ibn Manzoor, Mohammad bin Mokarram, 1416, Lassan al-Arab, Dar Allahia al-Terah, Beirut.

10. Jebee Ameli, Zayn al-Din (Shahid Sani), 1418, Explanation of Mu'al al-Din Faylaves, Beirut Publishing House, First Printing 
11. Jebee Ameli, Zayn al-Din bin Ali ibn Ahmad (Shahidisani), 1414, Masalak al-Alafam al-Taniqih Shari'ah al-Islam, Islamic Studies Institute.

12. Khoei, Abolqasem, 2010, Tenuikhh Al-Aroo al-Watseqi, Publishing Lotfi, Qom.

13. Katouzian, Naser, 1380, proof and proof of proof, Q 1, Tehran Publishing Sq

14. Korkhi, Ali ibn Hussein, 1411, Jame al-Majsoed, Naser-e-Jabat al-Eslamiyah, Beirut.

15. Meshkini Ardebili, Ali, 1995, Terminology, Nasr-e-Hadi, Qom.

16. Najafi, Mohammad Hassan, 1988, Jewel-e-Kalam Fi Description of Shira'-al-Islam, research by Abbas Qouchani, Tehran, Dar Elek-al-Islam.

17. Naraghi, Researcher, Documentary-Shi'a, 1419, Q1, Mashhad, Al-Bait Institute (pbuh) publishing house.

18. Ragheb Isfahani, Hussein ibn Muhammad, 1419, Qur'anic verses, Behrouz Publishing House.

19. Shift, William, 2005, Introduction to International Criminal Court, Translator: Seyyed Baqer Mir Abbasi and Hamid Alhoei Nazari Tehran, Forest Publishing.

20. Sadr, Mohammad Baqir, 1426, Lessons in the field of science, The Institute of Al-Nasr al-Islami AlRa'a'a Lajma'a al-Mudarsin, Qom, seventh edition.

21. Tarihi, Fakhreddin, 1412, Assembly of Al-Bahrain, Qom, Institute of Al-Dawlat Electrics, Second Edition

22. Walaee, Isa, 2009, Anatomical culture of the terminology of principles, publication.

23. Zobydi, Mohammad Morteza, 2009, Taj al-Ursu, Jahar Al-Qamous, Publishing Research Institute, Qom. 